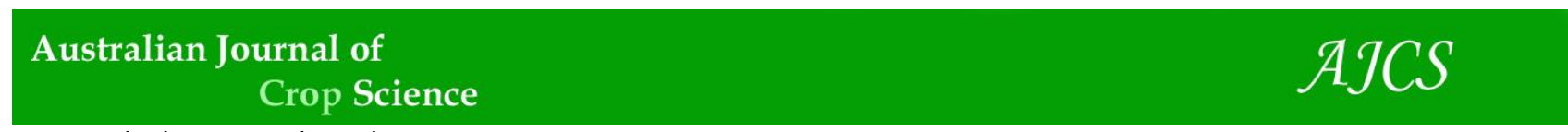

AJCS 11(03):352-359 (2017)

ISSN:1835-2707

doi: 10.21475/ajcs.17.11.03.pne273

\title{
Effects of nitrogen fertilization on yield components in a corn-palisadegrass intercropping system
}

\author{
Rodrigo Estevam Munhoz de Almeida ${ }^{1}$, José Laércio Favarin ${ }^{2}$, Rafael Otto ${ }^{3}$, Clovis Pierozan Junior ${ }^{2}$, \\ Silas Maciel de Oliveira ${ }^{2}$, Tiago Tezotto ${ }^{2}$, Bruno Cocco Lago ${ }^{2}$
}

\author{
${ }^{1}$ Embrapa Pesca e Aquicultura - Quadra 104 Sul, Av. LO 1, No 34, Conjunto 4. CEP 77020-02. Palmas, TO, \\ Brasil \\ ${ }^{2}$ Departamento de Produção Vegetal. Escola Superior de Agricultura "Luiz de Queiroz" (ESALQ-USP). Av. \\ Padua Dias, 11. CEP 13418-900, Piracicaba,SP, Brazil \\ ${ }^{3}$ Departamento de Ciência do Solo. Escola Superior de Agricultura "Luiz de Queiroz" (ESALQ/USP). Av. Padua \\ Dias, 11. CEP 13418-900. Piracicaba, SP, Brazil
}

*Corresponding author: rodrigo.almeida@embrapa.br

\begin{abstract}
Pasture and grain crop intercropping is considered an alternative for increasing biomass production during the winter periods in Brazil for the establishment of no-tillage systems. We studied nitrogen $(\mathrm{N})$ fertilization rates in a corn-palisadegrass intercropping system that would allow both corn and biomass production without a reduction in corn yield. A field trial was carried out in São Desidério, Bahia - Brazil using a complete block experimental design with a 5 x 2 factorial layout with two factors: $\mathrm{N}$ rate (control, $50,100,150$, and $200 \mathrm{~kg} \mathrm{ha}^{-1} \mathrm{~N}$ ) and two cropping systems (corn with or without palisadegrass). Both corn and palisadegrass were sown simultaneously with $\mathrm{N}$ fertilizer applied at sowing. The measurements included corn biomass, grain yield and $\mathrm{N}$ uptake. In addition, palisadegrass biomass was assessed at corn harvest and at three consecutive times during the winter. There was an interaction between $\mathrm{N}$ rates and the intercropping system. Grain yield was affected by intercropping when $\mathrm{N}$ fertilizer rates were lower than $100 \mathrm{~kg} \mathrm{ha}^{-1}$, but above that rate, corn grain yield reached $10,000 \mathrm{~kg} \mathrm{ha}^{-1}$ and was similar with or without palisadegrass. Nitrogen fertilizers also positively affected corn $\mathrm{N}$ uptake. There was no residual effect of $\mathrm{N}$ fertilization on palisadegrass biomass production during the sampling periods. However, the biomass of the palisadegrass increased during the winter period and reached $5,000 \mathrm{~kg} \mathrm{ha}^{-1}$ of dry matter by the following season. There was no corn yield reduction when corn was intercropped with palisadegrass using nitrogen rates above $100 \mathrm{~kg} \mathrm{ha}^{-1}$. In addition, it is possible to increase biomass production for the establishment of no-tillage systems in Brazil.
\end{abstract}

Keywords: Urochloa ruziziensis; maize; urea; pasture establishment; no tillage.

\section{Introduction}

Plant intercropping is an important technique in the croplivestock integration system (CLI) for the establishment of pastures, for forage production in the off-season or for attaining residues for use in no-tillage production in the next season. With this technique, it is possible to achieve greater production of vegetal biomass to cover the soil (Borghi et al., 2012; Ceccon et al., 2013; Crusciol et al., 2013), and it also allows the establishment of pastures for livestock (Crusciol et al., 2012; Fisher et al., 2012; Borghi et al., 2013). This technique can provide many benefits for the soil-plant system, such as reducing soil loss by erosion (Montenegro et al., 2013; Lima et al., 2014), a reduction in the occurrence of weeds (Amossé et al., 2013; Scopel et al., 2013) and the maintenance of a vegetated area, allowing for greater nutrient cycling and the reduction of nutrient loss in the off-season (Fraser et al., 2013; Hashemi et al., 2013).

The CLI technique promotes an increase in the use efficiency of the land and natural resources such as water, light and nitrogen (N) (Mao et al., 2012; Jannoura et al., 2014), thus establishing the sustainable management of agricultural and livestock production (Bell et al., 2014;
Crusciol et al., 2014; Lemaire et al., 2014; Salton et al., 2014).

For the success of plant intercropping, the competitive advantage of the main grain producer plant must be assured. One strategy for doing so is to maintain the forage species via shading during the cereal production cycle. Competitive interactions and synergism between the intercropped plants are simultaneous, and for the success of the system, the interspecific interactions must promote the growth, nutrient absorption and grain yield of the dominant plant while at the same time reduce these parameters in the subordinate plant during the coexistence period (Zhang and $\mathrm{Li}, 2003$ ). After harvesting the main crop, the secondary plant is able to recover its growth and achieve a situation similar to its sole cultivation.

Corn (Zea mays L.) (dominant plant) and palisadegrass (Urochloa spp.) (subordinate plant) intercropping is a widely used technology in the CLI system in Brazil. With the use of appropriate management techniques, the intercropping of the two species do not compromise corn yield (Borghi et al., 2012; Costa et al., 2012; Borghi et al., 2013; Ceccon et al., 2013). During the coexistence period, palisadegrass has its physiological parameters altered via a slower rate of 
development when compared to its individual cultivation (Araujo et al., 2011; Baldé et al., 2011). Still, it is an efficient system for the establishment and renewal of pastures because 70 days after corn harvest, the regrowth of palisadegrass presents a biomass establishment similar to palisadegrass grown exclusively (Portes et al., 2000).

One of the barriers to the large-scale adoption of CLI in Brazil is the concern from farmers that intercropping corn with other species will limit its growth and yield due to competition for water, light and nutrients. To ensure the necessary nutrition for corn growth and its competitive advantage over palisadegrass, nitrogen fertilization must be done in a quantity that enhances the growth of corn to quickly shade the subordinated crop, among other factors. Corn is a highly responsive crop to $\mathrm{N}$ and a temporary $\mathrm{N}$ deficiency in the early stages could jeopardize its efficiency and dominance over palisadegrass. Therefore, it is necessary to know the dynamics of $\mathrm{N}$ in the corn-palisadegrass intercropping system for the proper establishment of the CLI. At the same time, little is known about the residual effects of nitrogen fertilization on the development and establishment of grasslands after harvesting the main crop.

The objective of this research was to assess the effects of nitrogen fertilization on the interaction between intercropped corn and palisadegrass and the residual effects of $\mathrm{N}$ in the development of palisadegrass after corn harvest.

\section{Results and discussion}

\section{Corn yield}

An interaction was observed between doses of $\mathrm{N}$ and cropping system for grain yield and total dry matter of corn (Table 2). For these two variables, the interaction was due to palisadegrass undermining the performance of corn plants in situations without $\mathrm{N}$ or with a low supply of $\mathrm{N}$, but there was no effect on corn when $\mathrm{N}$ was applied to the system above $100-150 \mathrm{~kg} \mathrm{ha}^{-1}$ (Figure 2a, b).

The corn yield with palisadegrass with no $\mathrm{N}$ application was $7,087 \mathrm{~kg} \mathrm{ha}^{-1}, 19 \%$ lower than the corn monocrop, which was $8,765 \mathrm{~kg} \mathrm{ha}^{-1}$. With $50 \mathrm{~kg} \mathrm{ha}^{-1}$ of $\mathrm{N}$ fertilization, corn yield with palisadegrass was $8,999 \mathrm{~kg} \mathrm{ha}^{-1}, 7 \%$ lower than the corn monocrop, which produced $9,726 \mathrm{~kg} \mathrm{ha}^{-1}$. At $100 \mathrm{~kg} \mathrm{ha}^{-1}$ of $\mathrm{N}$ fertilization, intercropped corn yielded $10,237 \mathrm{~kg} \mathrm{ha}^{-1}$, $1.5 \%$ lower than the corn monocrop $\left(10,389 \mathrm{~kg} \mathrm{ha}^{-1}\right)$. Fertilization at $150 \mathrm{~kg} \mathrm{ha}^{-1}$ of $\mathrm{N}$ provided similar yields for the cropping systems, with $0.4 \%$ higher yield for the cornpalisadegrass intercropping system (Fig. 2a). Thus, corn yield with $\mathrm{N}$ rates above $100 \mathrm{~kg} \mathrm{ha}^{-1}$ of $\mathrm{N}$ were virtually the same between the two systems, showing that there was no loss to corn yield when corn was intercropped with palisadegrass and supplied with an adequate amount of $\mathrm{N}$.

Similarly, the total dry matter accumulation of corn (grain + shoot) followed the same pattern as grain yield (Fig. 2b). Corn intercropped with palisadegrass without $\mathrm{N}$ fertilization and with $50 \mathrm{~kg} \mathrm{ha}^{-1}$ of $\mathrm{N}$ produced $17 \%$ and $9.7 \%$ less dry matter than the corn monocrop, respectively. At rates above $100 \mathrm{~kg} \mathrm{ha}^{-1}$ of $\mathrm{N}$, dry matter production was similar at approximately $20,000 \mathrm{~kg} \mathrm{ha}^{-1}$.

These results show the need for nitrogen fertilization at the appropriate time and rate. $\mathrm{N}$ enhanced the initial growth of corn, which promoted faster shading of palisadegrass and thus established palisadegrass as the subordinate plant, an essential component to the success of intercropped systems (Zhang and LI, 2003). Gava et al. (2010) demonstrated the influence of $\mathrm{N}$ on biomass accumulation in the early development of corn plants. According to these authors, the maximum dry matter production rate was achieved approximately 46 days after the emergence of corn, which was $86 \mathrm{~kg} \mathrm{ha}^{-1}$ day $^{-1}$ with the accumulation of $233 \mathrm{~kg} \mathrm{ha}^{-1}$ of corn dry matter without an $\mathrm{N}$ supply in this period. However, with the application of $200 \mathrm{~kg} \mathrm{ha}^{-1}$ of $\mathrm{N}$ in the same period of 46 days after emergence, the maximum growth rate was 108 $\mathrm{kg} \mathrm{ha}^{-1}$ day $^{-1}$ with the accumulation of $374 \mathrm{~kg} \mathrm{ha}^{-1}$ of dry matter. This demonstrates the positive impact of $\mathrm{N}$ in the initial growth of the crop, which contributes to the competitive advantage of corn over palisadegrass.

The intercropping of corn and palisadegrass without an $\mathrm{N}$ supply or with a low amount of $\mathrm{N}$ delayed the initial growth of corn. There was longer period of sunlight on palisadegrass, which increased the photosynthetic rate and water and nutrient uptake of palisadegrass. Therefore, the competitive potential between species was increased, thus reducing corn yield and growth.

According to regression analysis, corn yield showed a quadratic response, which was highly significant according to the rates of $\mathrm{N}$ in both cropping systems (Fig. 2a). The maximum points indicate that the highest yield for monocropped corn was $10,805 \mathrm{~kg} \mathrm{ha}^{-1}$ at a rate of $186 \mathrm{~kg} \mathrm{ha}^{-1}$ of $\mathrm{N}$. In the corn-palisadegrass intercropping system, the maximum yield was $10,836 \mathrm{~kg} \mathrm{ha}^{-1}$ at a rate of $167 \mathrm{~kg} \mathrm{ha}^{-1}$ of $\mathrm{N}$ (Fig. 2a).

The supply of $\mathrm{N}$ on corn yield was not affected by the presence of palisadegrass, which corroborates the data from other studies (Borghi et al., 2012; Costa et al., 2012; Borghi et al., 2013; Ceccon et al., 2013). The maximum achieved yield was similar among the cropping systems; however, for corn intercropped with palisadegrass, the maximum yield was obtained at $20 \mathrm{~kg} \mathrm{~N} \mathrm{ha}^{-1}$ less than the corn monocrop system. Recently, some authors have reported the ability of palisadegrass to retain $\mathrm{N}$ in an ammoniacal form in the soil via the inhibition of bacteria active in nitrification and thus acting as a natural nitrification inhibitor (Subbarao et al., 2007; Subbarao et al., 2013). This may explain the higher maximum yield obtained with a lower $\mathrm{N}$ rate in the cornpalisadegrass intercropping system compared to the corn monocrop. The absorption of $\mathrm{N}$ in its ammoniacal form requires lower energy expenditure for its assimilation in relation to its nitrate form (Bloom et al., 1992). It also promotes the acidification of the rhizosphere when absorbed (Hinsinger et al., 2003), a fact that favors root growth and absorption of other nutrients (Bloom et al., 2002; Jing et al., 2010) and increases microorganism activity in the rhizosphere (Mahmood et al., 2005).

\section{N extraction by corn}

There was no difference in $\mathrm{N}$ extraction by corn shoots (Shoots $\mathrm{N}$ ) according to $\mathrm{N}$ rate or cropping system (Table 3 ). However, $\mathrm{N}$ extraction by corn grains (Grain $\mathrm{N}$ ) and total $\mathrm{N}$ extraction by corn (Total $\mathrm{N}$ ) responded significantly and similarly to the rates and cropping systems, and there was no significant interaction between these factors (Table 3 ). Between the two cropping systems, the largest extraction of $\mathrm{N}$ was in the system without palisadegrass, with $8 \%$ more for NG and 7\% more for NTOT (Table 3).

The difference between the systems occurred as the monocrop system without an $\mathrm{N}$ application showed $30 \%$ and $21 \%$ more for NG and NTOT than the intercropping system without $\mathrm{N}$, which contributed to a higher average extraction between the systems (Table 3 ). On the other hand, comparing the systems at the $\mathrm{N}$ rate of $200 \mathrm{~kg} \mathrm{ha}^{-1}$ of $\mathrm{N}$, this difference was $5 \%$ and $1 \%$ more extraction in the intercropping system 


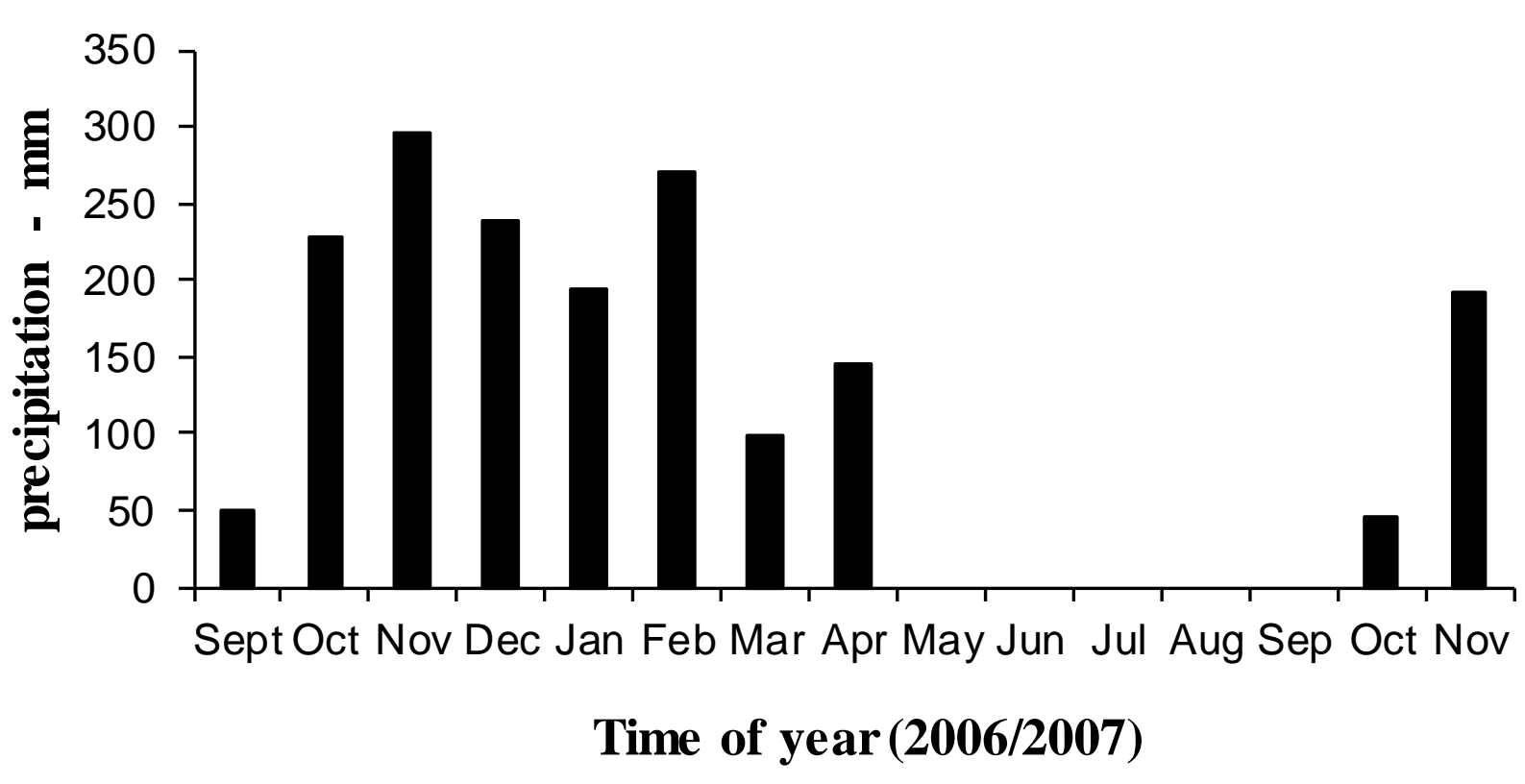

Fig 1. Precipitation during 2006/2007 growing season in São Desidério-BA, Brazil. Experimental period during November 2006 until November 2007.

Table 2. Analysis of variance between $\mathrm{N}$ rates and system (corn monocrop and corn intercropped with palisadegrass) for yield and total dry matter of corn.

\begin{tabular}{llll}
\hline & S.V. & Corn Yield & Total DM \\
\hline \multirow{3}{*}{ Pr $>$ F } & Rate & $<0.0001^{* * * *}$ & $<0.0001^{* * * *}$ \\
& System & $0.0018^{* *}$ & $0.0124^{* *}$ \\
& R x S & $0.0064^{* *}$ & $0.0322^{*}$ \\
CV \% & & 4.93 & 7.21 \\
\hline
\end{tabular}

${ }^{\mathrm{ns}}$ not significant, ${ }^{*}$ significant at $5 \%,{ }^{* *}$ signific ant at $1 \%,{ }^{* * *}$ signific ant at less than $0.1 \%$ probability of error by the $\mathrm{F}$ test.
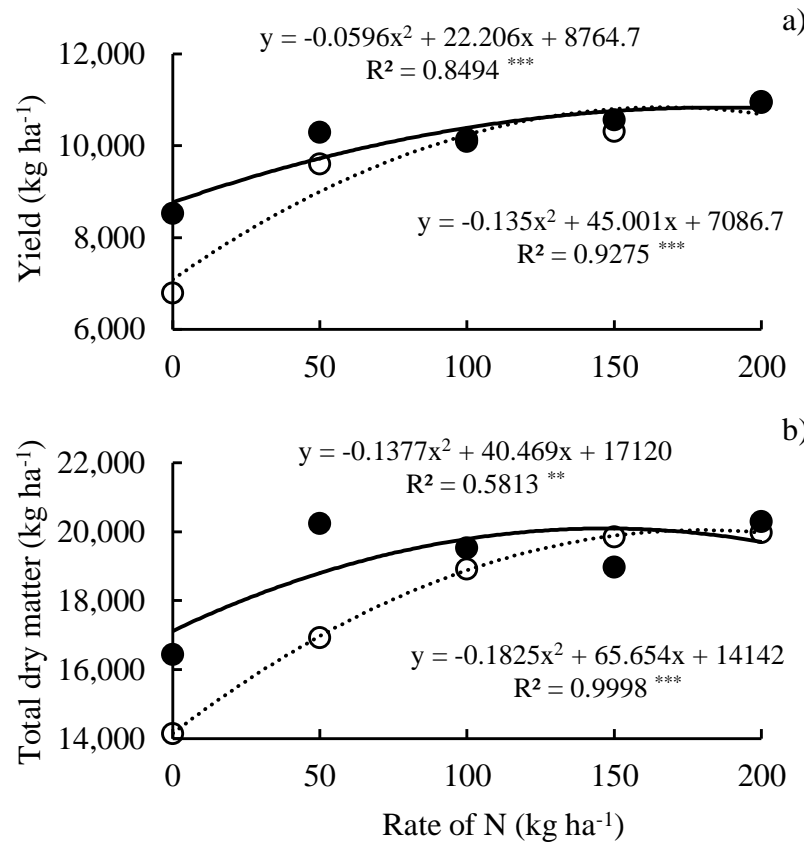

- Sole corn o Corn + palisadegrass

Fig 2. Corn grain yield and total dry matter as related to $\mathrm{N}$ rates and system (corn monocrop and corn intercropped with palisadegrass). ${ }^{* * *}$ significant at less than $0.1 \%$ probability of error by the $\mathrm{F}$ test. 
Table 3. $\mathrm{N}$ extraction in corn grains (Grain N), corn shoot (Shoot $\mathrm{N}$ ) and all corn plant (Total N) between $\mathrm{N}$ rates and system (corn monocrop and corn intercropped with palisadegrass).

\begin{tabular}{lllll}
\hline System & Rate & Grain N & Shoot N & Total N \\
\hline & 0 & $-\mathrm{kg} \mathrm{ha}^{-1}-$ & 61 & 156 \\
& 50 & 95 & 79 & 197 \\
Corn monocrop & 100 & 119 & 79 & 198 \\
& 150 & 119 & 72 & 193 \\
Average & 200 & 121 & 75 & $192 A$ \\
& & 141 & 73 & 122 \\
Corn intercropped with & 0 & $119 \mathrm{~A}$ & 55 & 172 \\
palisadegrass & 50 & 67 & 59 & 205 \\
& 100 & 113 & 63 & 213 \\
Average & 150 & 116 & 85 & $178 B^{*}$ \\
& 200 & 134 & 79 & $<0.0001^{* * *}$ \\
Pr>F & & $110 B$ & 68 & $0.0323^{*}$ \\
& Rate & $<0.0001^{* * *}$ & $0.0799^{\mathrm{ns}}$ & $0.1546^{\mathrm{ns}}$ \\
\hline
\end{tabular}

${ }^{\mathrm{ns}}$ not signific ant, " signific ant at $5 \%,{ }^{*}$ signific ant at less than $0.1 \%$ probability of error by the $\mathrm{F}$ test.
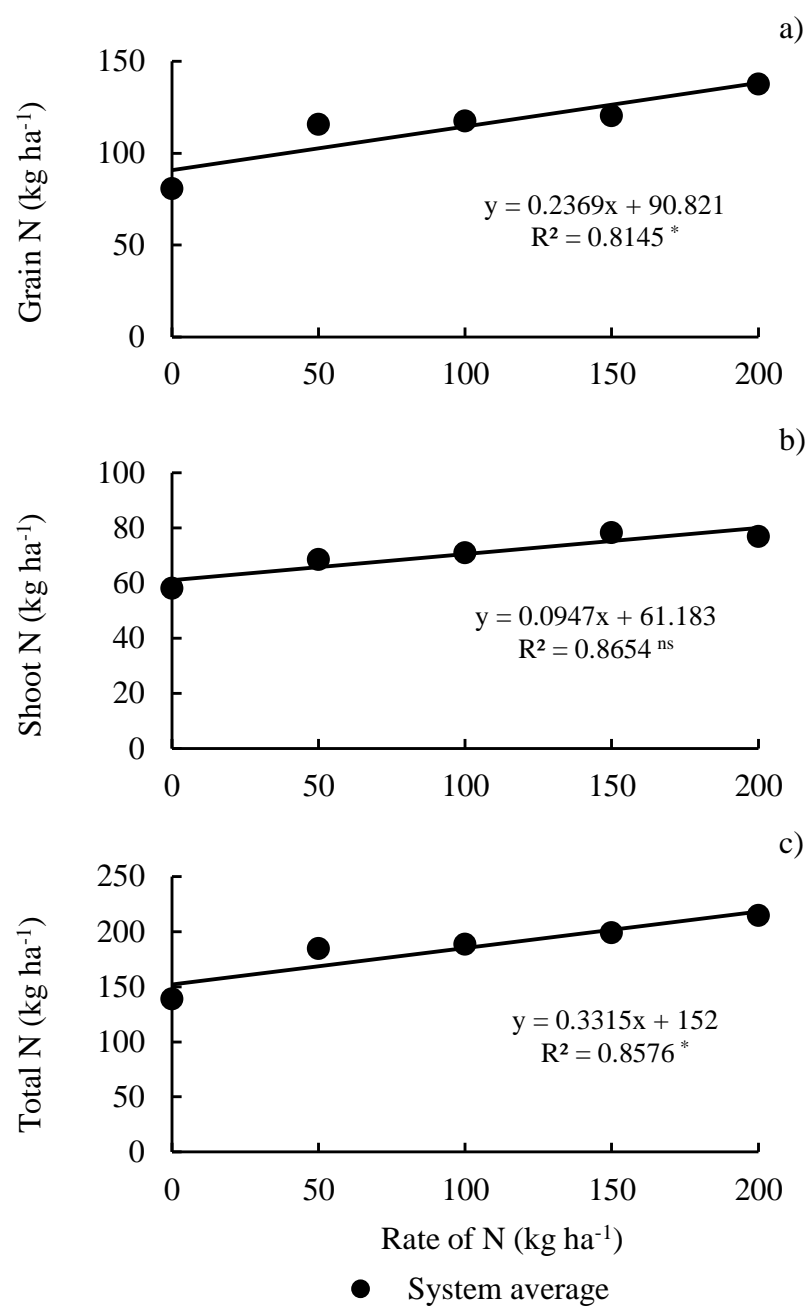

Fig 3. Nitrogen extraction by corn grains (a), corn shoot (b) and all corn plant (c) as related to $\mathrm{N}$ fertilization, on average of both cropping systems. ${ }^{\text {ns }}$ not significant, ${ }^{*}$ significant at $5 \%$ probability of error by the $\mathrm{F}$ test. 
Table 4. Analysis of variance between $\mathrm{N}$ rates and sampling periods (date) for palisadegrass dry matter.

\begin{tabular}{|c|c|c|}
\hline \multirow{4}{*}{$\operatorname{Pr}>\mathrm{F}$} & S.V. & Palisadegrass DM \\
\hline & Rate & $0.0315^{*}$ \\
\hline & Date & $<0.0001^{* * *}$ \\
\hline & Rate $\mathrm{x}$ Date & $0.9659^{\mathrm{ns}}$ \\
\hline CV \% & & 8.03 \\
\hline
\end{tabular}

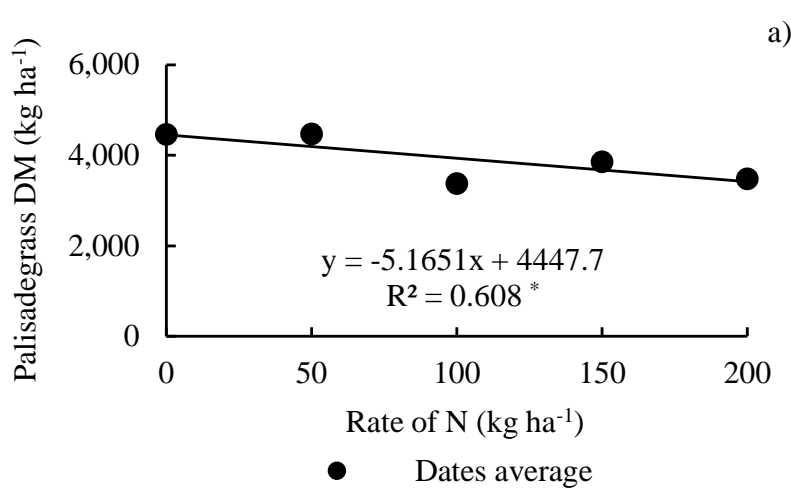

a)

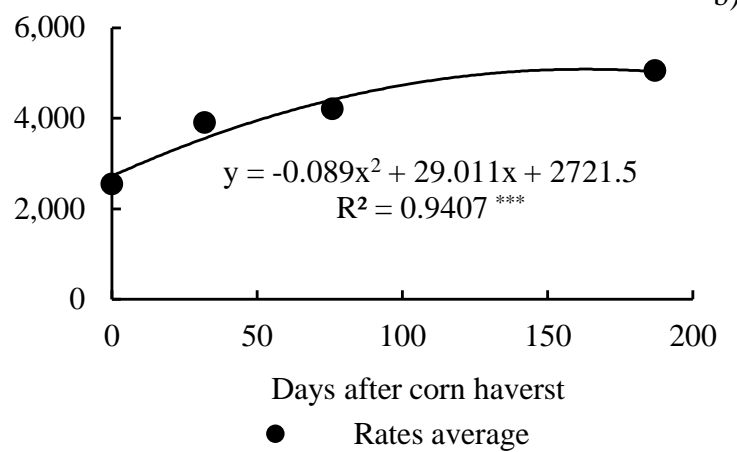

Fig 4. Biomass of palisadegrass as related to $\mathrm{N}$ rates or periods of sampling (date). ${ }^{*}$ significant at $5 \%,{ }^{* * *}$ significant at less than $0.1 \%$ probability of error by the $\mathrm{F}$ test.

compared to the monocrop system for NG and NTOT, respectively, proving the need for nitrogen fertilizer for the success of the intercropping system.

The extraction of $\mathrm{N}$ increased linearly according to the $\mathrm{N}$ rate for NG and NTOT (Fig. 3a, c). These results reflect yield because the extraction of $\mathrm{N}$ depends on this factor. Once yield was higher in a monocrop system without $\mathrm{N}, \mathrm{N}$ extraction follows the same pattern. In the fertilized system, productivity was similar between the systems, leading to similar $\mathrm{N}$ extraction.

Based on these results, it can be inferred that the intercropping of corn and palisadegrass did not affect corn nutrition and yield when $\mathrm{N}$ was supplied in rates above 100 $\mathrm{kg} \mathrm{ha}^{-1}$. This rate is close to that recommended for corn in order to reach its optimal yield (Cantarella et al., 1997). If $\mathrm{N}$ is supplied in adequate amounts to corn, it will enhance its initial development, promote the shading of palisadegrass and minimize competition.

\section{Palisadegrass after corn harvest}

Dry matter production of palisadegrass was influenced by the rate of $\mathrm{N}$ and harvest time, and there was no interaction between these factors (Table 4).

The dry matter of palisadegrass was higher without $\mathrm{N}$ application in the intercropping system. The residual $\mathrm{N}$ at any evaluated rate did not enhance the growth of palisadegrass after corn harvest (Fig. 4a). In the absence of N, corn had its initial growth reduced, and it took longer to shade the area and suppress the growth of palisadegrass. In this situation, palisadegrass accumulated more matter during the development of corn, which is an unwanted situation where the intercropping system triggers interspecific competition with a reduction in corn yield and total dry matter (Fig. 2a, b). The palisadegrass yielded $4,447 \mathrm{~kg} \mathrm{ha}^{-1}$ dry matter without an $\mathrm{N}$ application, with a $5.16 \mathrm{~kg} \mathrm{ha}^{-1}$ reduction in the growth of dry matter for each kilogram of $\mathrm{N}$ applied.

After corn harvest, palisadegrass became the only crop in the field and resumed its growth over the days (Fig. 4b) with access to photosynthetically active radiation. With the average rates of $\mathrm{N}$, palisadegrass had accumulated $2,721 \mathrm{~kg}$ $\mathrm{ha}^{-1}$ of dry matter at corn harvest, with an increase of $837 \mathrm{~kg}$ $\mathrm{ha}^{-1}$ in the first 32 days after corn harvest. From the $32^{\text {nd }}$ to the $76^{\text {th }}$ day after corn harvest, palisadegrass accumulated another $853 \mathrm{~kg} \mathrm{ha}^{-1}$ of dry matter, and from the $76^{\text {th }}$ to the $187^{\text {th }}$ day, it accumulated $622 \mathrm{~kg} \mathrm{ha}^{-1}$. On the day of desiccation to install the next crop, or 200 days after corn harvest, palisadegrass had accumulated $5,034 \mathrm{~kg} \mathrm{ha}^{-1}$ of dry matter (Fig. 4b). If the drought that occurred in the area during the experiment were considered (Fig. 1), this amount of biomass would be considered high and similar to that reported in other studies (Portes et al., 2000; Pacheco et al., 2011).

The residual effects of $\mathrm{N}$ applied to corn did not favor the growth of palisadegrass after corn harvest since most palisadegrass production was under condition without $\mathrm{N}$; there was no change in the growth of palisadegrass induced by $\mathrm{N}$ rates at all assessments after corn harvest (Fig. 4). This is an indication that the $\mathrm{N}$ applied at the beginning of the corn growing season was used primarily by the corn crop, which extracted quantities of 180 to $200 \mathrm{~kg} \mathrm{ha}^{-1}$ of $\mathrm{N}$ in the higher rates (Table 3). This result is in agreement with the observations made by other authors; in order to get a palisadegrass response to $\mathrm{N}$ after the corn harvest, a new nitrogen fertilization should be carried out (Pariz et al., 2011; Borghi et al., 2014).

This observation confirms that the crop effect caused by shading from corn plants, namely, the lack of radiation incidence on palisadegrass, is an important factor for minimizing interspecific competition. After corn harvest, when palisadegrass has access to sunlight, its growth was enhanced regardless of the $\mathrm{N}$ rate previously applied. Nitrogen fertilization is important for grain yield, but in the case of the intercropping system, it is essential to promote the growth of corn and favor the shading of palisadegrass as quickly as possible to avoid a reduction in corn yield via competition with palisadegrass.

The lack of competition between palisadegrass and corn when adequate nitrogen fertilization is carried out, as observed in this study, is because palisadegrass absorbs very 
little $\mathrm{N}$ when cultured in an intercropping system. The results of Almeida (2014) proved that palisadegrass grown in an intercropping system absorbs at most $5 \%$ of the nitrogen fertilizer, while most of the $\mathrm{N}$ is absorbed by corn.

Fernandes et al. (2008) demonstrated that the use of residual $\mathrm{N}$ in subsequent crops is small and maxed at 3.7\%; these results corroborate this study since $\mathrm{N}$ was essential for the increase in corn yield and did not affect the growth of palisadegrass after corn harvest. Therefore, cornpalisadegrass intercropping proved to be an interesting strategy that achieved high corn yield while allowing the production of vegetal biomass up to $5,000 \mathrm{~kg} \mathrm{ha}^{-1}$ of dry matter.

\section{Materials and Methods}

\section{Plant materials}

Urochloa ruziziensis (syn. Brachiaria ruziziensis) was the palisadegrass species intercropped with corn (Zea mays) hybrid 'Impacto'. Palisadegrass was sown at a density of 10 $\mathrm{kg}$ seed ha ${ }^{-1}$ (viable seed $=34 \%$ ). The corn hybrid was sown in $0.76 \mathrm{~m}$ row spacing and five plants per meter at a population of 60,000 plants $\mathrm{ha}^{-1}$. Each plot consisted of six corn rows that were $10 \mathrm{~m}$ long $\left(45.6 \mathrm{~m}^{2}\right)$

\section{Site description}

The experiment was carried out in the city of São Desidério, Bahia State (BA) - Brazil. The soil of the experimental area was classified as Typic Haplustox (USDA, 1999), containing $140,210,200,210$ and $220 \mathrm{~g} \mathrm{~kg}^{-1}$ of clay in the $0-20,20-40$, 40-60, 60-80 and 80-100 cm layers, respectively. Chemical analyzes were performed according to Raij et al. (2001) and the results are shown in Table 1 . The local climate is classified as Aw according to Köppen, which is characterized as hot and humid in the rainy season, and the dry season is set in winter. The experimental area is located $840 \mathrm{~m}$ above sea level, with an average annual temperature of $20^{\circ} \mathrm{C}$ and an average rainfall of $1,500 \mathrm{~mm}$ per year. The monthly data on rainfall during the experiment are presented in Figure 1.

\section{Experimental design and treatments}

The experimental design used was randomized blocks in a 5 x 2 factorial scheme with five rates of $\mathrm{N}$ (without $\mathrm{N}, 50,100$, 150 and $200 \mathrm{~kg} \mathrm{ha}^{-1}$ of N) and two cropping systems (corn monocrop and corn intercropped with palisadegrass). The $\mathrm{N}$ source was urea applied only at sowing in a lateral furrow, ten centimeters from the corn rows and eight centimeters deep.

\section{Crop Management}

The palisadegrass was sown between corn rows on the same day as corn sowing. At tillering of the palisadegrass, a suboptimal rate of nicosulfuron $\left(6 \mathrm{~g} \mathrm{ha}^{-1}\right)$ was applied to limit the initial growth of palisadegrass and $1,760 \mathrm{~g} \mathrm{ha}^{-1}$ of atrazine was applied for weed control. The soil was limed before the experiment was initiated, and 37 days before corn sowing, 90 $\mathrm{kg} \mathrm{ha}^{-1} \mathrm{~S}$ and $102 \mathrm{~kg} \mathrm{ha}^{-1} \mathrm{Ca}$ were applied by broadcast application. Seven days before sowing, $100 \mathrm{~kg} \mathrm{ha}^{-1} \mathrm{P}_{2} \mathrm{O}_{5}$ and $200 \mathrm{~kg} \mathrm{ha}^{-1} \mathrm{~K}_{2} \mathrm{O}$ were applied.

\section{Sampling and evaluations}

Corn harvest was performed on May 10, 2007 with the assessments made in the central area of each plot. Dry matter of the shoots of the corn plants and grain matter were determined. Samples were also taken to determine the concentration of nutrients and the subsequent calculation of $\mathrm{N}$ extraction by corn in the shoots (Shoot $\mathrm{N}$ ) and the grains $($ Grain $\mathrm{N}$ ) and total $\mathrm{N}$ (Total $\mathrm{N})$. To calculate the yield, grain moisture was determined and corrected to $130 \mathrm{~g}$ of water $\mathrm{kg}^{-1}$ of dry matter. The first evaluation of palisadegrass occurred at corn harvest (May 10) by collecting all the plant material from an area of $0.5 \times 1.52 \mathrm{~m}\left(0.76 \mathrm{~m}^{2}\right)$ located in the center of each plot for the determination of fresh matter. A quarter of the palisadegrass collected was subsampled to determine dry matter after oven drying at $65^{\circ} \mathrm{C}$ for 72 hours and was sent for an analysis of the nutrients in the plant tissue. This procedure was repeated on June 11, July 25 and November 13 (at 32, 76 and 187 days after the corn harvest).

\section{Statistical procedure}

The data were subjected to a homogeneity of variance test (Box-Cox) and an analysis of variance. When the F-value was significant, regression analysis was used for the quantitative factors and a means comparison test (LSD) was used for the qualitative factors. Additionally, the necessary procedures were performed when there were interactions between the factors.

\section{Conclusions}

At $\mathrm{N}$ rates below $100 \mathrm{~kg} \mathrm{ha}^{-1}$ of $\mathrm{N}$, there is competition between palisadegrass and corn, resulting in a corn yield decrease in the intercropping system. From $100 \mathrm{~kg} \mathrm{ha}^{-1}$ of $\mathrm{N}$ and upwards, there is no yield reduction in corn intercropped with palisadegrass. There is no residual effect of nitrogen fertilization on the growth of palisadegrass after corn harvest.

\section{Acknowledgments}

We thank Wilson Hideki Horita for providing experimental field and financial support, the technical team for their efforts in conducting this research, and Agronomist Leonardo Shigeyuki Sugimoto for his contribution and dedication. The authors thank Fundação Agrisus for funding this research.

\section{References}

Almeida REM (2014) Fertilização nitrogenada no consórcio milho-braquiária em solos de clima tropical úmido no sistema de integração lavoura-pecuária. 149 p. PhD Thesis, Escola Superior de Agricultura Luiz de Queiroz. Universidade de São Paulo. Piracicaba.

Amossé C, Jeuffroy MH, Celette F, David C (2013) Relayintercropped forage legumes help to control weeds in organic grain production. Eur J Agron. 49: 158-167.

Araujo LCD, Santos PM, Mendonça FC, Lima NRCDB (2011) Development of maize and palisadegrass plants cultivated in intercrop under water deficit. Rev Bras Zootecn. 40: 1397-1404.

Baldé AB, Scopel E, Affholder F, Corbeels M, Silva FAM, Xavier JHV, Wery J (2011) Agronomic performance of notillage relay intercropping with maize under smallholder conditions in Central Brazil. Field Crop Res. 124(2): 240251. 
Bell LW, Moore AD, Kirkegaard JA (2014) Evolution in crop-livestock integration systems that improve farm productivity and environmental performance in Australia. Eur J Agron. 57: 10-20.

Bloom AJ, Sukrapanna SS, Warner RL (1992) Root respiration associated with ammonium and nitrate absorption and assimilation by barley. Plant Physiol. 99: 1294-1301.

Bloom AJ, Meyerhoff PA, Taylor AR, Rost TL (2002) Root development and absorption of ammonium and nitrate from the rhizosphere. J Plant Growth Regul. 21(4): 416-431.

Borghi E, Crusciol CAC, Nascente AS, Mateus GP, Martins PO, Costa C (2012) Effects of row spacing and intercrop on maize grain yield and forage production of palisade grass. Crop Pasture Sci. 63: 1106-1113.

Borghi E, Crusciol CAC, Mateus GP, Nascente AS, Martins PO (2013) Intercropping time of corn and palisadegrass or guineagrass affecting grain yield and forage production. Crop Sci. 53(2): 629-636.

Borghi E, Crusciol CAC, Trivelin PCO, Nascente AS, Costa C, Mateus GP (2014) Nitrogen fertilization $\left({ }^{15} \mathrm{NH}_{4} \mathrm{NO}_{3}\right)$ of palisadegrass and residual effect on subsequent no-tillage corn. Rev Bras Cienc Solo. 38: 1457-1468.

Cantarella H, Raij VB, Camargo CEO (1997) Cereais. In: Raij BV, Cantarella H, Quaggio JA, Furlani AMC (ed) Recomendação de adubação e calagem para o Estado de São Paulo. (Boletim técnico 100). Instituto Agronômico de Campinas, Campinas.3.

Ceccon G, Staut LA, Sagrilo E, Machado LAZ, Nunes DP, Alves VB (2013) Legumes and forage species sole or intercropped with corn in soybean-corn succession in Midwestern Brazil. Rev Bras Cienc Solo. 37(1): 204-212.

Costa PM, Villela SDJ, Leonel FP, Araújo SAC, Araújo KG, Ruas JRM, Coelho FS, Andrade VR (2012) Intercropping of corn, brachiaria grass and leguminous plants: productivity, quality and composition of silages. Rev Bras Zootecn. 41(10): 2144-2149.

Crusciol CAC, Mateus GP, Nascente AS, Martins PO, Borghi E, Pariz CM (2012) An innovative crop-forage intercrop system: early cycle soybean cultivars and palisadegrass. Agron J. 104(4): 1085-1095.

Crusciol CAC, Nascente AS, Mateus GP, Borghi E, Leles EP, Santos NCB (2013) Effect of intercropping on yields of corn with different relative maturities and palisadegrass. Agron J. 105(3): 599-606.

Crusciol CAC, Nascente AS, Mateus GP, Pariz CM, Martins PO, Borghi E (2014) Intercropping soybean and palisade grass for enhanced land use efficiency and revenue in a no till system. Eur J Agron 58: 53-62.

Fernandes FCS, Libardi PL, Trivelin PCO (2008) Parcelamento da adubação nitrogenada na cultura do milho e utilização do $\mathrm{N}$ residual pela sucessão aveia preta-milho. Ciênc Rural. 38: 1138-1141.

Fisher J, Tozer P, Abrecht D (2012) Livestock in no-till cropping systems - a story of trade-offs. Anim Prod Sci. 52(4): 197-214.

Fraser PM, Curtin D, Harrison-Kirk T, Meenken ED, Beare MH, Tabley F, Gillespie RN, Francis GS (2013) Winter nitrate leaching under different tillage and winter cover crop management practices. Soil Sci Soc Am J. 77(4): 1391-1401.

Gava GJC, Oliveira MW, Silva MA, Jerônimo EM, Cruz JCS, Trivelin PCO (2010) Produção de fitomassa e acúmulo de nitrogênio em milho cultivado com diferentes doses de ${ }^{15} \mathrm{~N}$-uréia. Semin-Cienc Agrar. 31(4): 851-862.
Hashemi M, Farsad A, Sadeghpour A, Weis SA, Herbert SJ (2013) Cover-crop seeding-date influence on fall nitrogen recovery. J Soil Sci Plant Nutr. 176(1): 69-75.

Hinsinger P, Plassard C, Tang C, Jaillard B (2003) Origins of root-mediated $\mathrm{pH}$ changes in the rhizosphere and their responses to environmental constraints: A review. Plant Soil. 248(1): 43-59.

Jannoura R, Joergensen RG, Bruns C (2014) Organic fertilizer effects on growth, crop yield, and soil microbial biomass indices in sole and intercropped peas and oats under organic farming conditions. Eur J Agron. 52(B): 259270.

Jing J, Rui Y, Zhang F, Rengel Z, Shen J (2010) Localized application of phosphorus and ammonium improves growth of maize seedlings by stimulating root proliferation and rhizosphere acidification. Field Crop Res. 119(2): 355-364.

Lemaire G, Franzluebbers A, Carvalho PCF, Dedieu B (2014) Integrated crop-livestock systems: Strategies to achieve synergy between agricultural production and environmental quality. Agric Ecosyst Environ. 190: 4-8.

Lima PLT, Silva MLN, Curi N, Quinton J (2014) Soil loss by water erosion in areas under maize and jack beans intercropped and monocultures. Ciênc Agrotec. 38(2): 129139.

Mahmood T, Kaiser WM, Ali R, Ashraf M, Gulnaz A, Iqbal Z (2005) Ammonium versus nitrate nutrition of plants stimulates microbial activity in the rhizosphere. Plant Soil. 277(1): 233-243.

Mao L, Zhang L, Li W, Werf WVD, Sun J, Spiertz H, Li L (2012) Yield advantage and water saving in maize/pea intercrop. Field Crop Res. 138: 11-20.

Montenegro AAA, Abrantes JRCB, Lima JLMP, Singh VP, Santos TEM (2013) Impact of mulching on soil and water dynamics under intermittent simulated rainfall. Catena. 109: 139-149.

Pacheco LP, Leandro WM, Machado PLOA, Assis RL, Cobucci T, Madari BE, Petter FA (2011) Produção de fitomassa e acúmulo e liberação de nutrientes por plantas de cobertura na safrinha. Pesqui Agropecu Bras. 46(1): 1725.

Pariz CM, Andreotti M, Bergamischine AF, Buzetti S, Costa NR, Cavallini MC (2011) Produção, composição bromatológica e índice de clorofila de braquiárias após o consórcio com milho. Arch Zootec. 60: 1041-1052.

Portes TDA, Carvalho SD, Oliveira ID, Kluthcouski J (2000) Análise do crescimento de uma cultivar de braquiária em cultivo solteiro e consorciado com cereais. Pesqui Agropecu Bras. 35(7): 1349-1358.

Raij B van, Andrade JC, Cantarella H, Quaggio JA (2001) Análise química para avaliação da fertilidade dos solos tropicais. Instituto Agronômico de Campinas, Campinas, 2001.

Salton JC, Mercante FM, Tomazi M, Zanatta JA, Concenço G, Silva WM, Retore M (2014) Integrated crop-livestock system in tropical Brazil: Toward a sustainable production system. Agric Ecosyst Environ. 190: 70-79.

Scopel E, Triomphe B, Affholder F, Silva FAM, Corbeels M, Xavier JHV, Lahmar R, Recous S, Bernoux M, Blanchart E, Mendes IC, Tourdonnet S (2013) Conservation agriculture cropping systems in temperate and tropical conditions, performances and impacts: a review. Agron Sustain Dev. 33(1): 113-130.

Subbarao GV, Wang HY, Ito O, Nakahara K, Berry WL (2007) $\mathrm{NH}_{4}{ }^{+}$triggers the synthesis and release of biological nitrification inhibition compounds in Brachiaria humidicola roots. Plant Soil. 290(1): 245-257. 
Subbarao GV, Sahrawat KL, Nakahara K, Rao IM, Ishitani M, Hash CT, Kishii M, Bonnett DG, Berry WL, Lata JC. (2013) A paradigm shift towards low-nitrifying production systems: the role of biological nitrification inhibition (BNI). Ann Bot. 112(2): 297-316.

USDA (1999) Soil Taxonomy. A basic system of soil classification for making and interpreting soil surveys. 2nd edn. USDA, Washington.
Zhang F, Li L (2003) Using competitive and facilitative interactions in intercropping systems enhances crop productivity and nutrient-use efficiency. Plant Soil. 248(12): 305-312. 